Konstantin Vadimovich Grigorichev, Doctor of Sociology, Vice-rector for research and international affairs, Professor of Irkutsk State University Irkutsk, Russia

Professor, Leading Researcher of the History and Political Sciences Department of Tomsk State University Tomsk, Russia grigoritchev@yandex.ru

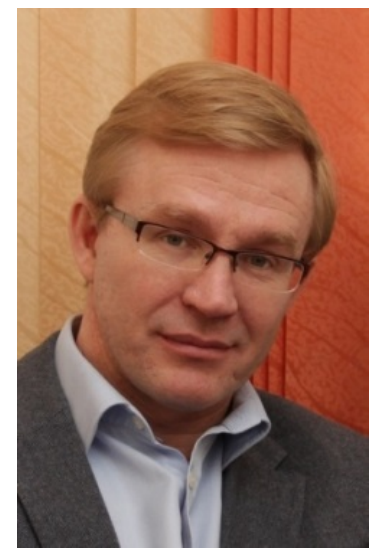

DOI 10.31554/978-5-7925-0571-1-2019-2-125-129

\title{
“PRIVATE SECTOR" OF THE RUSSIAN CITIES: FROM HERITAGE OF SOVIET URBANIZATION TO THE “INNER SUBURBS”
}

The report raises the problem of the spread of suburbanism as a lifestyle in the vast tracts of estate development, defined in Russian cities as the "private sector". It is shown that the "private sector" occupies a significant part of the space of provincial cities, but the specifics of its post-Soviet transformations remain beyond the research attention. On the basis of several variants, the hypothesis is proposed that it is the "private sector" and its communities that can perform as the main field for the spread of suburbanism in post-Soviet Russian cities.

Keywords: suburbanisation, "private sector”, inner suburbs.

“The post-socialist suburban revolution”, recorded by researchers as one of the key trends in urban development of post-Soviet countries in recent decades” [Stanilov, Sykora 2014], in Russian conditions is much less dynamic. Despite the fact that the suburbs of large cities remain the only points of preservation and even population growth [Mkrtchyan 2017; Grigorichev, 2018], it is still difficult to talk about a radical change in the role of suburbs in the settlement system in Russia. This is reflected in the relatively low growth rates of migration beyond the administrative boundaries of cities, and in the preservation of the model of using suburban housing as a second 
and/or seasonal as a base, and in the prevalence of urban "elite" housing as a sign of high social status. Suburban settlements often remain a zone of resettlement of migrants from rural areas as an effect of incomplete Soviet urbanization [Breslavsky 2014], a zone of forced resettlement of citizens displaced from prestigious urban areas as a result of reconstruction or economic instability [Kazakova 2017]. Living on the periphery of a large city often becomes a territorial stigma [Kazakova 2017], forming the image of suburbia as socially disadvantaged suburbs. Examples of mass movement of citizens to the suburbs [Grigorichev 2013] as a conscious choice of suburban lifestyle remain, rather, options for the possible future, but not the dominant trend.

One of the key reasons for this situation, in my opinion, lies in the specifics of the spatial, architectural and social organization of the Russian city. Express Soviet urbanization 1930-1950ss established significant specifics of development of the Soviet cities, one form of which was the so-called "private sector" - areas of low-rise individual housing construction, developing on the basis of the spontaneous development of migrants from the village, where rural practices of organisation of communities and everyday life were reproduced. Embodying the phenomenon defined by V. L. Glazychev as "urban slobodization" [1995], this sociospatial phenomenon persists in most Russian cities outside the metropolitan areas. Even in the largest cities-millionaires of Siberia (Omsk, Krasnoyarsk, Novosibirsk) "private sector" occupies vast arrays, not only filling the voids between blocks of multi-storey buildings, but also forming entire areas with a specific "non-urban" organization of space and communities, leaving a serious imprint on the nature of both spatial and social development of the city. In smaller cities-regional capitals the "private sector" often makes up a large part of the built-up area, and the population living here-a significant part of urban communities.

Since its formation this phenomenon has been described in power rhetoric and urban planning documentation as a temporary and marginal for the city. It was assumed that in the future this "side effect" of urbanization will give way to planned development within the framework of the concept of "socialist city". As a consequence, communities formed in "private sector" areas were seen as temporary, and their "non-urban" way of life as transitional, temporary state. The preservation of vast tracts of "private sector" in Russian cities has led to the preservation of this transition for decades. As a 
result, Russian cities have formed the phenomenon of transitional communities that preserve their marginal status throughout the life of the already two or three generations. In ordinary consciousness, power rhetoric and, often, in a few academic texts, areas of the "private sector" are a priori defined as areas of marginalized groups and often discursively criminalized. This perception of a significant segment of the urban space of Russian cities and the communities living in them persists to the present time, and the ideas about the post-Soviet transformations of the Russian city do not de facto apply to them.

At the same time, field observations in Omsk, Khabarovsk and a few more studied cases in Irkutsk show that it is the "private sector" that is becoming one of the most important reception spaces of suburbanism as a way of life. Visually, the most visible manifestations of the penetration of suburban lifestyle inside the city limits are the enclaves of cottage development, which arise on the borders of the arrays of the "private sector" with prestigious areas of multi-storey buildings, or with recreational spaces. Communities of such enclaves are formed on the model of gated community [Low 2003], which probably reflects the general post-Soviet trend of spatial and symbolic isolation of new elites [Gasior-Niemiec, Glasze, Pütz 2009; Hirt 2012]. The obvious differences from the adjacent "private sector" in the architectural appearance, in the organization of the living space and the estate are emphasized in a different way and the rhythm of life.

However, the emergence of such closed communities is not the dominant option for the penetration of suburbanism within the city limits. A much larger trend is the change in the appearance of the main body of the private sector. Long-term (more than 10 years) observations of a small area of the "private sector" of Irkutsk suggest that the key trend of its development was the transformation of the model of "inner suburbs". For example, one of the objects of my observation is a small street in the North-Western part of the city, constructing with tall buildings of which is not planned due to the nature of the soil (proximity to the floodplain), as stated in the general plan for the development of Irkutsk. During the observation of the 47 estates located here, 12 were completely rebuilt and significantly rebuilt another 17 . New and rebuilt houses differ from the original appearance of the "private sector" as a new layout and materials, and the presence of a full range of utilities based on local technologies (own water wells, water treatment systems, sanitation, etc.). Not only residential premises are being rebuilt, but also the 
space of the estate, which almost completely loses its supporting function (as a subsidiary farm), acquiring mainly recreational value. It is important to emphasize that among the owners of the rebuilt estates there are both representatives of the indigenous community (the second and third generation living in this locality) and visitors. Investments in capital construction together with changes in the organization of space and functions of estates, in my opinion, are a marker of reflexive choice of settlement outside of multi-storey buildings. A number of interviews collected in such localities confirm the choice of such a settlement as a special way of life, the closest to the characteristics of suburbanism [Walks 2013].

Thus, it seems to me possible to assume that one of the most popular variants of suburbanization in regional cities of post-Soviet Russia is the transformation of the "private sector" on the model of the inner suburbs. The spread of suburbanism here, despite its considerable scale, is poorly reflected in both academic and managerial discourse due to the stereotypical perception of such localities as marginal. However, the "private sector" can be a basic space distribution of suburbanism in modern Russia.

\section{References and sources}

Breslavsky A. S. Nezaplanirovanniye prigorody: selsko-gorodskaya migratsiya i rost Ulan-Ude $\mathrm{v}$ postsovetskiy period [Unplanned suburbs: rural-urban migration and the growth of Ulan-Ude in the post-Soviet period] / ed. by M. N. Baldano. Ulan-Ude: Publishing House of the BSC SB RAS, 2014. - 192 p.

Glazichev V. L. Slobodizatsiya strany Gardariki [Slobodisation of Gardariki country] // Other. Khrestomatiya novogo rossiyskogo samosoznaniya [Anthology of the new Russian identity]. - M.: Argus, 1995. - P. 63-68.

Grigorichev K. V. V teni bolshogo goroda. Sotsialnoye prostranstvo prigoroda [In the shadow of the big city. The social space of the suburb]. - Irkutsk: Ottisk, 2013. - $238 \mathrm{p}$.

Grigorichev K. V. Suburbanisatsiya na vostoke Rossii: regionalnaya mozaika globalnogo trenda [Suburbanization in the East of Russia: regional mosaic of global trend] // Respubliki na vostoke Rossii: traektorii ekonomicheskogo, demographicheskogo i territorialnogo razvitiya [Republics in the East of Russia: trajectory of economic, demographic and territorial development] / ed. by A. S. Breslavsky. Ulan-Ude: Publishing House of the BSC SB RAS, 2018. - P. 175-189.

Kazakova A. U. Prigorodny obraz zhizni v sovremennoy rossiyskoy provintsii. Sotsialnaya baza, problemy i perspektivy razvitiya [Suburban lifestyle in the modern Russian province. Social base, problems and prospects of development]. - Saratov: Vuzovskoye obrazovaniye [University education], 2017. - 259 p. 
Kazakova A. U. Territorialnaya stigma: soderzhaniye i znak otsenki [Territorial stigma: content and mark of assessment] // Sotsialniye i gumanitarniye znaniya [Social and humanitarian knowledge]. - 2017. - Vol. 3. - № 4(12). - P. 357-368.

Mkrtchyan N. V. Pristolichniye territorii Rossii: dinamika naseleniya i migratsionny balance [Russian capital territories: population dynamics and migration balance] // Chto mi znaem o sovremennykh rossiyskikh prigorodakh [What do we know about modern Russian suburbs?] / ed. by A. S. Breslavsky. - Ulan-Ude: Publishing House of the BSC SB RAS, 2017. - P. 26-36.

Gasior-Niemiec A., Glasze G., Pütz R. A Glimpse over the Rising Walls: The Reflection of Post-Communist Transformation in the Polish Discourse of Gated Communities // East European Politics \& Societies. - 2003. - Vol. 23. - N. 2. P. 244-265.

Hirt S. Iron Curtains: Gates, Suburbs and Privatization of Space in the Postsocialist City. - Oxford: Willey-Blackwell, 2012. - 252 p.

Low S. M. Behind the Gates: Life, Security and the Pursuit of Happiness in Fortress America. - New York and London: Routledge, 2003. - 275 p.

Stanilov K., Sykora L. (eds.) Confronting Suburbanization: Urban Decentralization in Post-socialist Central and Eastern Europe - Oxford: Willey-Blackwell, 2014. $-360 \mathrm{p}$. 